\title{
GULLY CAVITY IDENTIFICATION THROUGH ELECTRICAL RESISTIVITY TOMOGRAPHY
}

\author{
Leonardo Paioli Carrazza ${ }^{1}$, Cesar Augusto Moreira ${ }^{2}$ and Lívia Portes Innocenti Helene ${ }^{1}$
}

\begin{abstract}
Chaotic urban expansion often leads to hazardous environmental consequences. The absense of rainwater outflow management, coupled with low cohesion in some terrains is a geotechnical threat for the population since it may lead to gully formation. Geophysics allows for the diagnostic of main gully erosion by products, such as piping phenomena, which generates natural underground cavities. The electrical resistivity contrast between soil and hollow cavities, favors the employment of the DC Resistivity method. This paper describes the use of electrical resistivity tomography in a gully investigation case in São Pedro County (São Paulo, Brazil) to detect cavities formed in a process known as internal erosion or piping. Six parallel lines of electrical imaging were used as a mean to collect electrical resistivity values. Eighty-four electrodes were placed; one meter apart from each other in each acquisition line, with a five-meter interval between each line according to the Wenner-Schlumberger array. The results showed a high resistivity signature, probably due to the absence of filling in the cavities. The lateral integration of the sections in an isovalue map regarding cavity depth occurency reveals the length and ramifications of the pipings in the internal portions of the terrain.
\end{abstract}

Keywords: piping, electrical resistivity, electrical resistivity tomography.

RESUMO. A expansão urbana desordenada pode gerar graves consequências ao ambiente. A falta de planejamento no escoamento de águas pluviais, aliada à baixa coesão de alguns terrenos pode proporcionar o surgimento de voçorocas, cuja evolução pode resultar em riscos geotécnicos para a população ao redor. Neste sentido, a geofísica pode possibilitar um diagnóstico de produtos da evolução de voçorocas, como o fenômeno de piping, que consiste na geração natural de cavidades no solo. 0 contraste de resistividade elétrica entre o solo e o espaço vazio da cavidade possibilita, nestes casos, o uso do método da eletrorresistividade. Este trabalho descreve 0 uso de ensaios de tomografia elétrica (ERT) na investigação de uma voçoroca no município de São Pedro (SP), para a avaliação da continuidade de cavidades formadas por processos de erosão interna ou piping. Foram realizadas 6 linhas paralelas para medidas de resistividade elétrica, com 84 eletrodos espaçados de $1 \mathrm{~m}$ entre eles, de $5 \mathrm{~m}$ entre linhas, por meio do arranjo Wenner-Schlumberger. A correlação entre dados geofísicos e cavidades revelou uma assinatura geoelétrica de alta resistividade, possivelmente devido à ausência de preenchimento. A integração lateral das seções em mapas de isovalores para a profundidade de ocorrência das cavidades, revela 0 prolongamento e a ramificação de pipings em porções mais internas do terreno.

Palavras-chave: piping, resistividade elétrica, tomografia elétrica.

\footnotetext{
${ }^{1}$ Universidade Estadual Paulista - UNESP, Geoscience and Exact Science Institute, Geoscience and Environmental Science Graduation Program, Rio Claro Campus, 24-A Avenue, 1515, P0 Box 178, 13506-900 São Paulo, SP, Brazil. Phone: +55(19) 3526-2819 - E-mails: leopcarrazza@hotmail.com; liviapihelene@gmail.com 2 Universidade Estadual Paulista - UNESP, Geoscience and Exact Science Institute, Applied Geology Department, Rio Claro Campus, 24-A Avenue, 1515, P0 Box 178, 13506-900 São Paulo, SP, Brazil. Phone: +55(19) 3526-2819 - E-mail: moreirac@rc.unesp.br
} 


\section{INTRODUCTION}

Erosive processes arise from environmental transformations and can be further stimulated or hindered through human activity. In urban or agricultural regions, poor soil handling can lead to increased exposure to erosive processes such as deforestation and impermeabilization. These factors intensify surface outflow generating further erosive potential (Almeida Filho et al., 2004).

Landslides, and rills deepening into gullies can also accelerate such processes (Infanti Jr \& Fornasari Filho, 1998).

Gully formation can be associated with pipe cavities; underground cavities with pipe-like morphology, developed through the piping phenomenon. The phenomenon consists of water outflow remaining within permeable soil and removing particles that work as aggregation cement grains to maintain the soil's cohesion. Concentrated outflow can increase the cavity's dimensions and result in a landslip of the area above the cavity (Azevedo \& Albuquerque Filho, 1998; Hunt, 2006; Fell \& Fry, 2013).

The studies related to gully formation and development seek to stablish preventive measures, and also a way around this detrimental process (Hunt, 2006). In spite of erosion and gullying being natural occurences, they pose a serious threat to urban populations because of gullies's slope slides and collapses.

There is a real need for studies regarding the underground range of cavities, with direct or indirect measurements, in order to hold back pipe growth.

Geophysics is an indirect, non-invasive method of investigation, well established in mineral survey, environmental and geotechnical studies. This method has been applied in many studies of geotechnical risks and the results are commonly satisfactory (Dourado et al., 2001; Ahmed et al., 2003; Silva Junior et al., 2006; Lazzari et al., 2010; Pánek et al., 2010; Martinez Pagán et al., 2013).

\section{STUDY AREA}

The study area is located in São Pedro County, countryside of São Paulo State, 191km away from the capital city São Paulo. The area can be accessed from São Paulo, from Rodovia dos Bandeirantes, SP-349, then SP-135 and finally SP-304.

The county is located near important commercial regions such as Piracicaba, São Carlos and Rio Claro, and can be accessed from Rodovia Geraldo de Barros (SP-191) (Fig. 1).

Gully development is described by Almeida Filho et al. (2004) based on aerial photographies and local description of technical visits done since the 60's. Effective erosion stemmed from incorrect soil handling and occupation in the surrounding regions of São Pedro County.
Due to population growth the occupation of regions closer to the erosive feature was necessary. After 30 years, actions were taken ir order to bring erosion to a halt, such as ground dikes (which later crumbled) to connect two neighborhoods. The only effective procedure was the planting of vegetation in the soil; it helped to hold some of the erosive process back. In some parts of the gully, debri disposal was also allowed (Almeida Filho et al., 2004; Mathias, 2011).

\section{REGIONAL GEOLOGY}

Geologic Formations from Paraná Sedimentary Basin occur in the region of study: Grupo Itararé, Formations Tatuí, Irati, Corumbataí, Pirambóia and Botucatu. However, this paper will only address Pirambóia and Botucatu Formations.

The Piramboia Formation contains lithological unities composed by sandstone with medium to fine granulometry - yellow, white or red and subrounded grains - displaying intercalation of thin layers of silt and clay, it can also present some sedimentary structure as cross stratification (Schneider et al., 1974). The depositional enviroment is continental, fluvial and desertic. Simões \& Fittipaldi (1992) identified fossiles: arthropods conchostraceous and ostrachodes. The Pirambóia Formation is charachterized partially by clay sandstones, reddish-brown, fine to medium; it also presents silex levels (Oka-Fiori, 2002).

The Botucatu Formation is one-hundred meters thick, composed by reddish sandstones associated with eolic processes in desertic enviroments, sometimes presenting cross stratifications; there are also no fossiles identified in this type of formation (Schneider et al., 1974). According to Oka-Fiori (2002), the depositional enviroment can be associated with fluvial-lake systems, linked to meandering rivers and small lakes.

Fieldwork analysis revealed two layers, one of soil and another of altered rock. A two-meter thick soil layer above the rock was found; reddish-brown in colour at the bottom and grayish closer to the surface (Fig. 2). The grains were fine and subrounded.

This type of rock is present along the entire surface of gully slopes with a twenty-meter underground thickness. The sandstone presents creamy brownish color and fine to medium subrounded grains. Due to high alteration degree, it is not possible to identify sedimentary structures. The fresh rock can be reached through the removal of some sheets of alterated sandstones. Due to the high alteration degree, it is not possible to identify sedimentary structures.

Pipes occur near the contact point between the soil and local rock with a fourty-centimeter thick conglomerate level. 


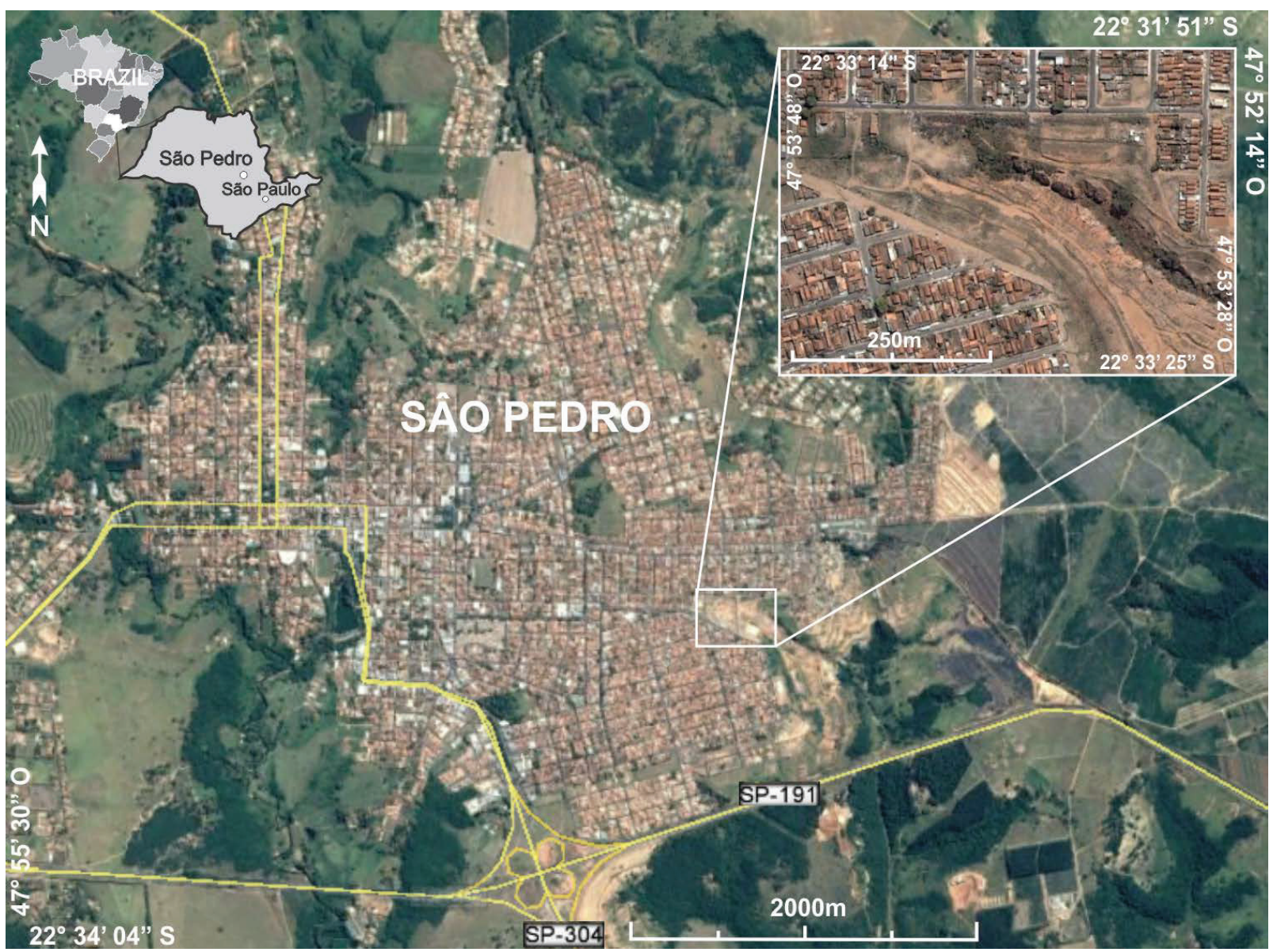

Figure 1 - Study area with details of the gully (Google Earth, 2014).

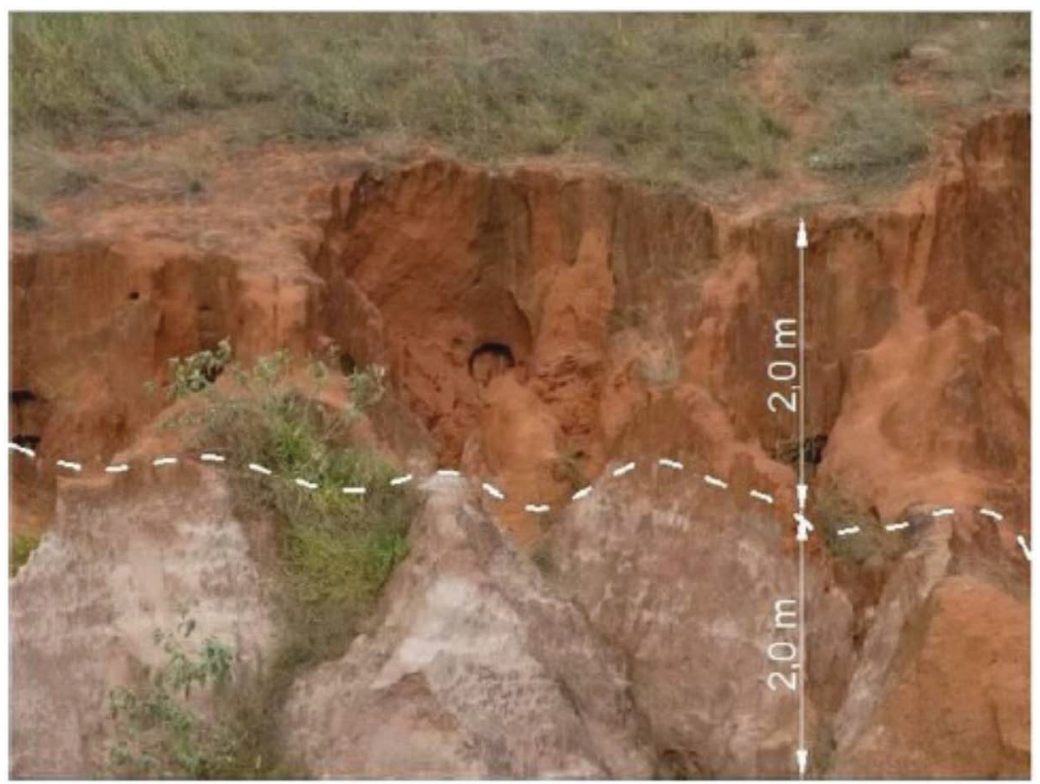

Figure 2 - Contact between soil and rock with pipe occurence. 


\section{GULLY AND PIPING FORMATION}

Gullies are developed in a process called linear erosion where pluvial water leaves grooves in the soil. If water keeps flowing in the grooves, they can be deepened into rills and later become gullies, where the phreatic level is intercepted (Infanti Jr \& Fornasari Filho, 1998).

Gullies are associated with collapsible soils that are composed mostly of sand. In this kind of soil, there is a high concentration of fine-grained sand and low amounts of silt and clay particles (Fell \& Fry, 2013), which work as cement in sand pores that mantain soil cohesion (Hunt, 2006).

When erosion is influenced by underground water such as phreatic level, gullies can develop through piping erosion. Water removes soil particles, opens small cavities that concentrate water flow and increase cavities dimensions (Azevedo \& Albuquerque Filho, 1998; Infanti Jr \& Fornasari Filho, 1998).

Just as regional and local geology shows, the Piramboia Formation is susceptible to the development of gullie erosion due to sandstone composition with low quantities of clay and silt. With the removal of the cement grains, the sand in this geologic formation can develop piping phenomena.

\section{MATERIAL AND METHODS}

The DC Resistivity method is based on generating an electric field by injecting an electric current $(I)$ through metal rods, called the transmitter circuit (Sheriff, 1989). The electric potential $(\Delta V)$ produced by this field is then captured by a receiver circuit, which can also be represented by metallic rods or nonpolarizable electrodes.

The procedure of data acquisition consists of generating current and injecting it into the soil for electrical potential measurement produced by the interation with materials with known properties. Lateral variations show informations about heterogeneities related to mineral constitution, or geological structures such as faults, dikes, contacts, etc. (Kearey et al., 2002; Telford et al., 2004).

The employment of the ERT (Electrical Resistivity Tomography) method for natural cavities (pipes) detection is based on the contrast of electrical properties between mineral grains and its absence in the cavities, which can be filled with air or water. This filling is conditioned to the occuring cavities depth, soil thickness, phreatic level oscilations, and climate conditions; such as dry and rain seasons.

The hybrid Wenner-Schlumberger arrangement was adopted. It consists in the alignment of a series of electrodes and the selection of four electrodes on each measurement. An external electrode pair is assigned to current transmission and an internal pair to voltage readings. The lateral movement of this device along with the constant distancing of current electrodes from respective voltage electrodes (a two-dimensional product) enables lateral investigations at multiple depths.

The measurement was done with the Terrameter LS resistivimeter. The equipment allows for automatic resistivity measurements, charging and SP.

The data was then processed within the Res2Dinv software (GEOTOMO, 2003), which allows 2D electrical imaging pseudosections to be modeled based on the measured physical parameter. The program was developed in order to allow inversion of large amounts of data (200 to 21000) from a system with several electrodes (25 to 16000). The 2D model used in the program divides the pseudo-section into rectangular blocks, which are then represented through the adjustment of field measurements. This sort of optimization aims to reduce the difference between the apparent resistivity values, calculated and measured in the field, by adjusting the block model resistivity; the difference is then expressed in the RMS (Root Mean Square) error.

The data generated after the 2D inversion was gathered in a single file and it was later used as a database for generating pseudo-3D models and depth maps. This process was developed in the Oasis Montaj platform with 2D data obtained from the Res2Dinv software. The information was interpolated and modeled using a minimum curvature algorithm - in order to enhance extreme values in a pseudo-3D block model - so that electric resistivity tomography lines could be placed.

Each point of the 3D final model was turned into a block with dimensions conditioned to statistical criteria from the mesh sample. Geophysical models of 3D viewing generated from 2D sections can provide a clear understanding of the complexity of geological and hydrogeological structures, as the pollutant flow and the modeling of lithotypes or flux structures (Chambers et al., 2006; Aizebeokhai et al., 2011; Vieira et al., 2016; Cortês et al., 2016; Moreira et al., 2016).

\section{RESULTS AND DISCUSSION}

The Wenner-Schlumberger hybrid array was employed in six electrical tomography lines of data acquisition spanning eighty-four meters in different levels of the gully (Fig. 3). Each line was placed five meters apart, while electrodes where placed one meter apart from each other in each line.

The contrast of electrical resistivity was encountered as high values associated with cavity occurence (Fig. 4).

Six inversion models of electrical resistivity were generated 


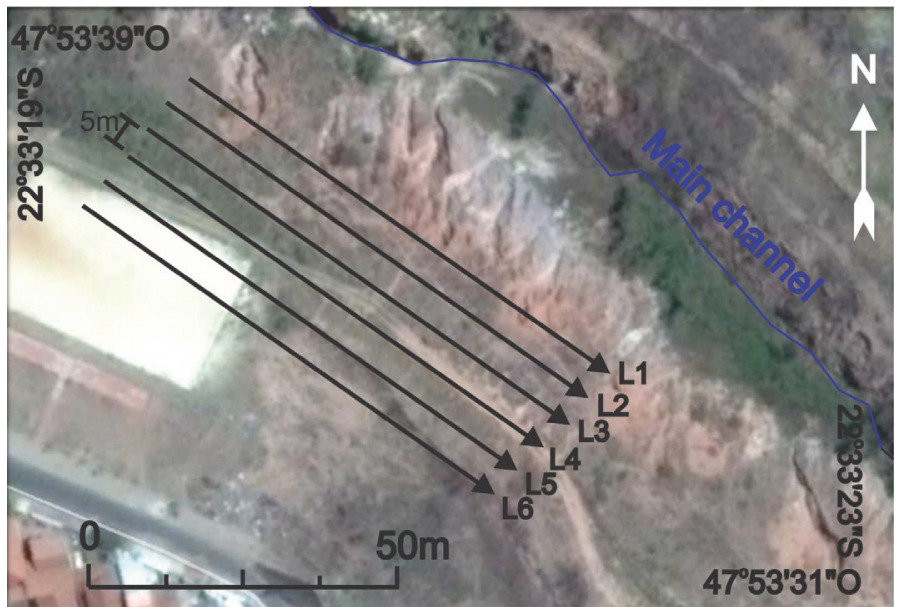

Figure 3 - Aerial view of lines of data acquisition: line 1 (L1) to line 6 (L6). (Adapted from Google Earth, 2014).

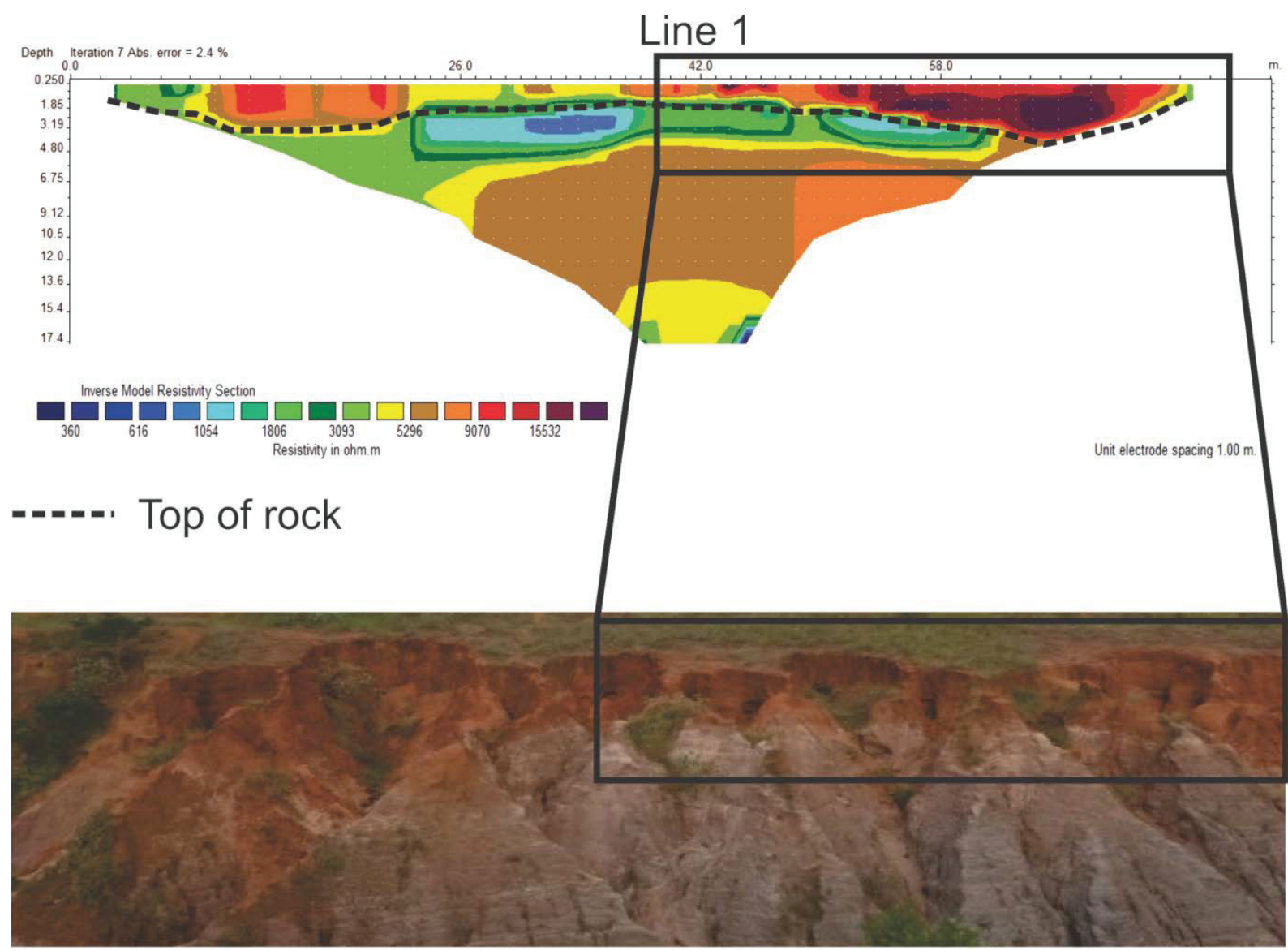

Figure 4 - Inversion model of line 1 (L1) with cavities.

after data processing. The inversion models (L1 to L6) are shown in Figure 5.

Values are expressed in different colors: warm colors represent high resistivity values and cool colors represent low val- ues. The generated sections showed great value variation between $300 \Omega \mathrm{m}$ and $16000 \Omega \mathrm{m}$. Linear scale was adopted for resistivity values beacause the resistivity logarithm would made the contrasts disappear. The RMS errors presented low values. Most of 


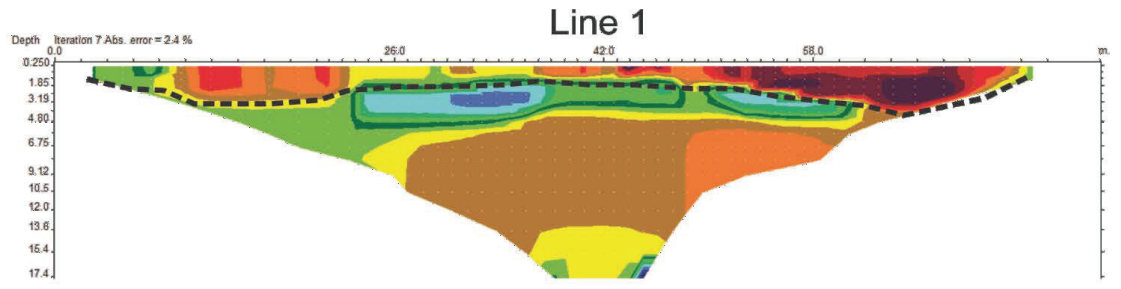

Line 2

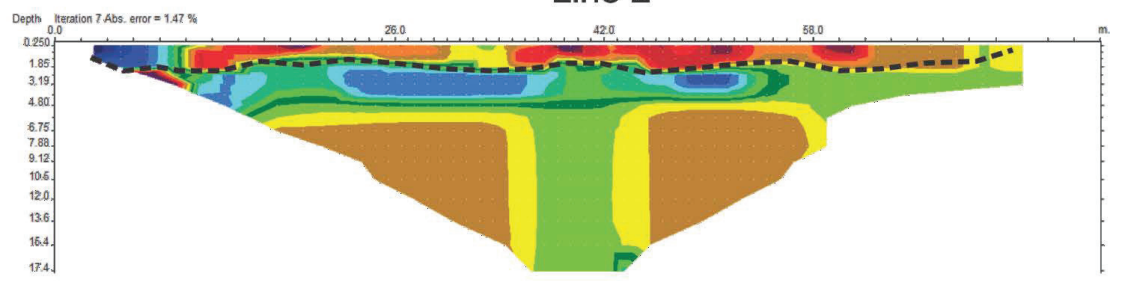

Line 3

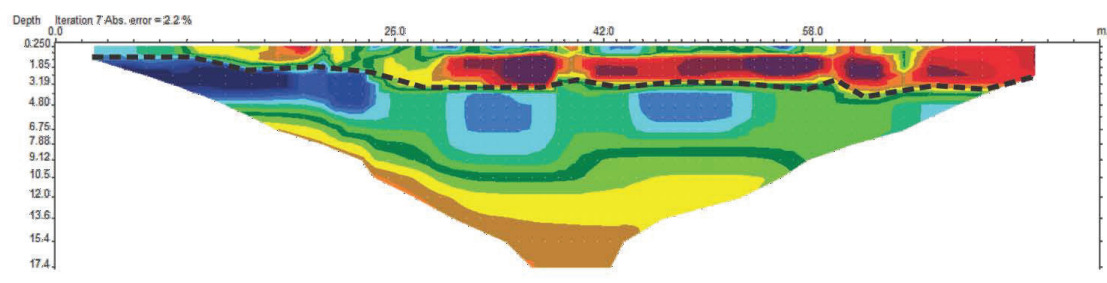

Line 4

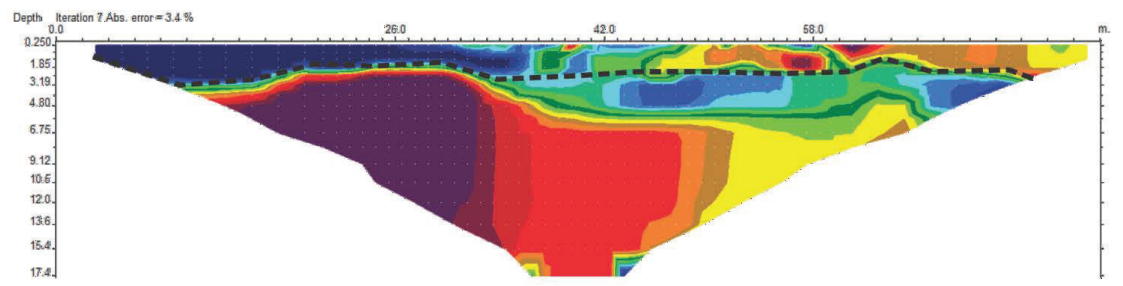

Line 5

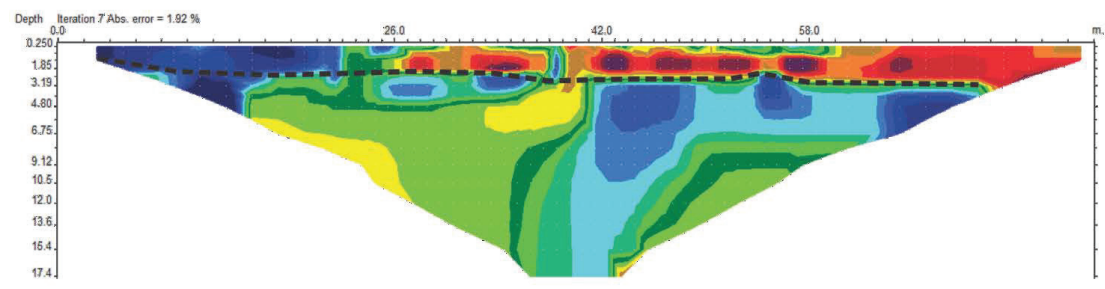

Line 6
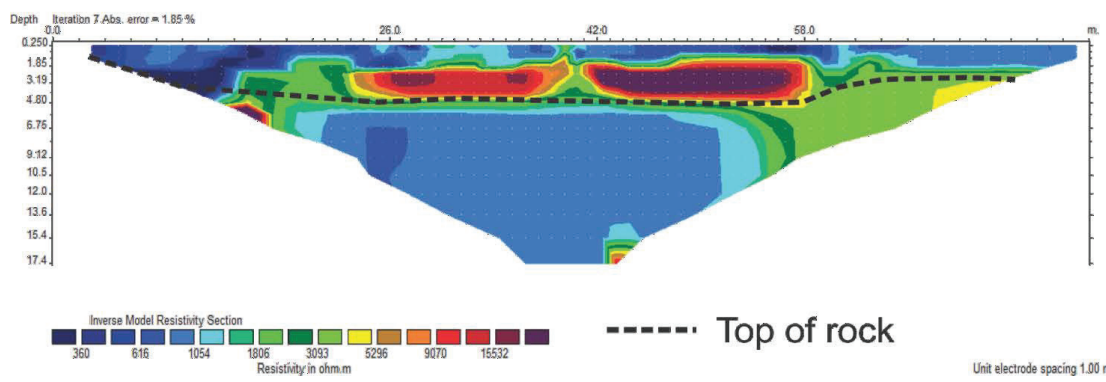

Figure $\mathbf{5}$ - Inversion models 1 to 6 . 
the lines showed high resistivity values near the rock-soil contact point. Lower resistivity values occur below the contact point as alterated rock depth increases.

Line 1 was closer to the edge of the gully channel and visible cavities, compared to the other lines. The highest resistivity region is fourty two meters deep, while the lowest values were collected below it.

The high resistivity values can be linked to cavities filled with air. The low resistivity values below the high resistivity zones can be associated with water-saturated rock.

Lines 2, 3, 5 and 6 followed the same pattern from line 1 in which high resistivity values occur near the surface, which can represent cavities filled with air (Fig. 5). Since all lines were parallel, high values can be linked to continuities from the appearing cavities in line 1. As lines distanced from the edge of the gully channel, low resistivity value zones increased.

Line 4 presented the widest variation of electrical resistivity values. They were detected only two meters deep and only at the fifty-eight meter surface section. This can represent continuity of the cavities detected in previous sections.

A peculiar high resistivity value zone was found at the eightmeter surface section, four meters deep. However, an intersection of the electrical tomography line with an underground sewer pipe inside the gully was discovered, thus explaining the phenomenon.

The concrete sewer pipe was fifty centimeters in diameter and it was almost completely filled with air, hence offering high resistance to current passage (Fig. 6). The injected current could not penetrate the pipe to generate the potential difference or could not reach the sand below the feature.

Therefore, values below the concrete pipe were generated as high resistivity, and so were values from inside it; sandstone values were different from values obtained in previous lines. The lower resistivity zone was bigger than in the previous line and spanned the whole line at a three-meter depth.

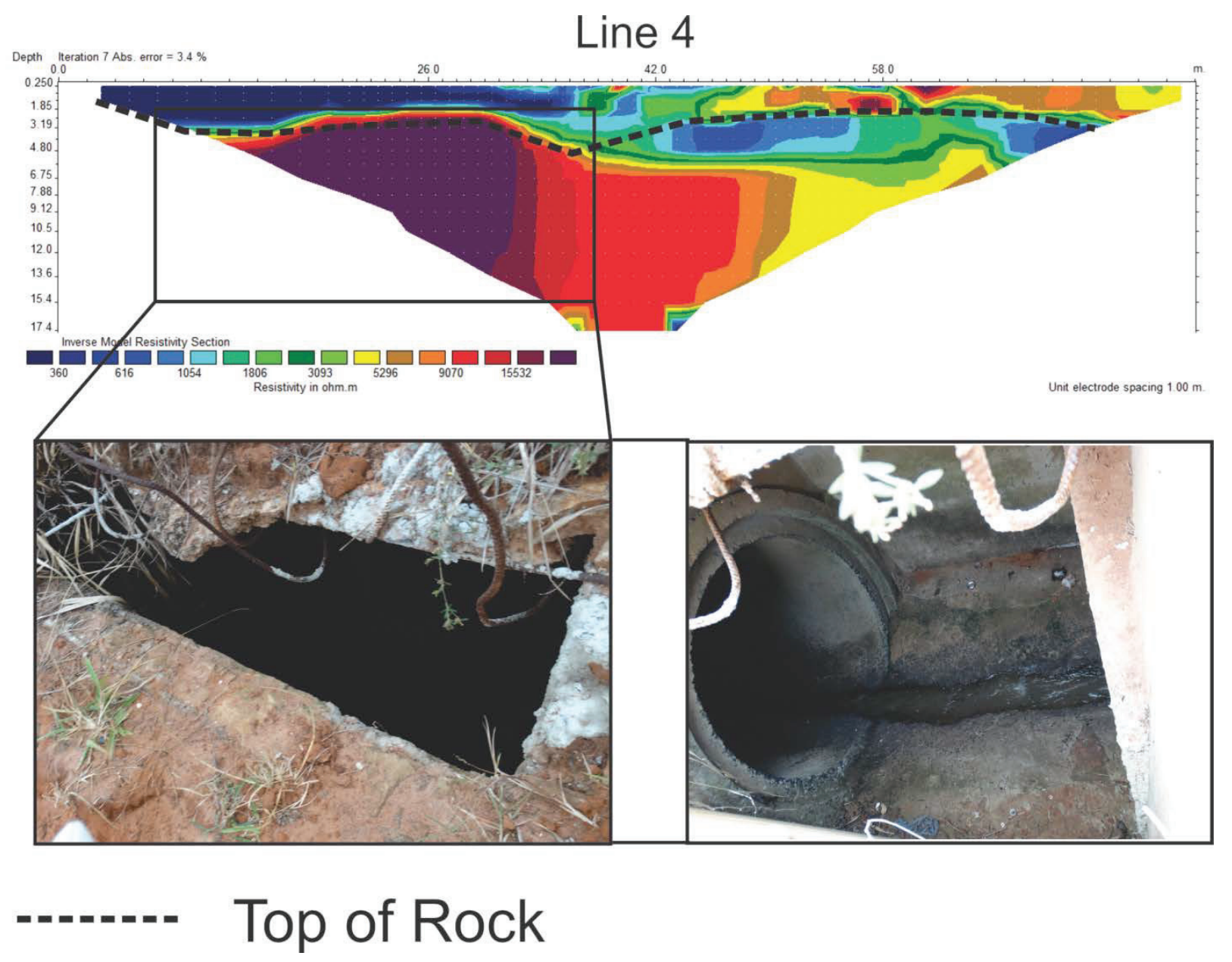

Figure 6 - Line 4 with local sewer pipe. 


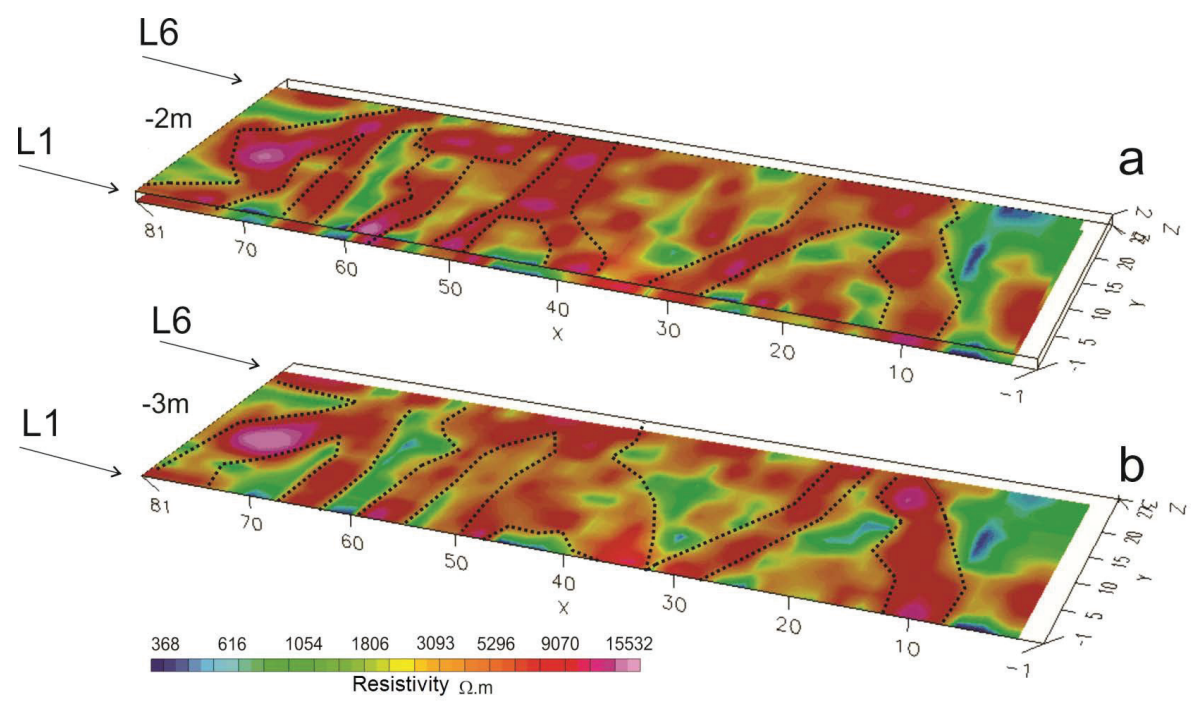

Figure 7 -3D visualization of electrical resistivity values in a) $2 \mathrm{~m}$ depth; b) $3 \mathrm{~m}$ depth, with featured probable occurrence of cavities.

High resistivity values were not pervasive, except for a noise in line 4. Generally, high resistivity values identified in line 1 could be related to posterior lines in similar distances and depths.

Therefore, this continuity of high resistivity values can be related to pipe presence and its continuity below the surface. The results matched the ones obtained in Dourado et al. (2001) and Lazzari et al. (2010).

The geophysical sections data was integrated in order to spacially demonstrate how resistivity values were spread under the surface at two and three meter depths. The $X$-axis values show the electrical imaging position while the $Y$-axis displays line positions of data acquisition. Warm colors indicate high resistivity values; cool colors indicate low values (Fig. 7).

Based on the figure it is possible to notice the spacial distribution of high resistivity at two (Fig. 7a) and three meter depths (Fig. 7b). The 7a figure shows the distribution of high resistivity values for the depth where the top of the rock was located. It is also possible to notice that high resistivity values appear more frequently from position fourty-two in the $X$-axis until the end of the electrical imaging line.

It is possible to infer high resistivity sectors, as more lines appear, which can indicate continuity of pipes below the surface. It is possible that lines 3 to 6 registered a higher cavity concentration, which resulted in larger dimensions for the values in the inversion model. In the last acquisition line, high resistivity values were concentrated which can also indicate cavity agglomeration.

Figure $7 \mathrm{~b}$ showed less high resistivity values in line 1 as compared to Figure 7a. More sectors with low resistivity values can be identified in line 1 positions.
The extension of high resistivity values shows that the cavities can be agglomerated below the surface as sections appear in the $Y$-axis. By contrasting both figures, it is possible to notice, in Figure $7 \mathrm{~b}$, an increase in dimensions of sectors where there are no high resistivity values. This can be explained because the threemeter deep reading is below the one identified with the cavities, in other words, the geoelectrical signatures are influenced mostly by the rock than by the air filling the cavities. In some sectors, they are also influenced by water saturation.

Both figures, 7a and 7b, indicate a possible cavity agglomeration (pipes) below the surface.

\section{CONCLUSIONS}

Geophysical data allowed for satisfactory results, making the relation between high resistivity values and high cavity concentration areas possible.

The one-meter spacing of electrodes was necessary in order to detect cavities with reasonable resolution using a small-scale setup. Such layout enabled easier identification of features that represent below the surface cavities.

However, not all high resistivity values represented air filled cavities. An anthropic structure - a concrete sewer pipe - crossed line 4, making its geoelectrical characterization impossible. The concrete did not allow for electric current propagation, which resulted in unrealistic readings for values below the structure.

Lines distant from the gully main channel were characterized by low resistivity values at a five-meter depth due to phreatic level shallowness. 
The integration of resistivity values in isovalue maps made possible for the discovery of lateral cavity continuity, through the identification of zones where cavities were possibly agglomerated. As such, this processing form can be employed in similar studies.

Since piping is a dynamic process, the DC Resistivity method can be a useful tool to monitor its evolution. By identifying cavities and its below the surface range, it is possible to estimate the risks they pose to nearby regions.

This paper demonstrates the application of DC Resistivity in cavity characterization and its potential in the planning and implementation of geotechnical gully recovery projects.

\section{REFERENCES}

AHMED S \& CARPENTER PJ. 2003. Geophysical response of filled sinkholes, soil pipes and associated bedrock fractures in thinly mantled karst, east-central Illinois. Environmental Geology, Illinois, USA, 44(6): 705-716.

AIZEBEOKHAI AP, OLAYINKA AI, SINGH VS \& UHUEGBU CC. 2011. Effectiveness of $3 \mathrm{D}$ geoelectrical resistivity imaging using parallel $2 \mathrm{D}$ profiles. International Journal of the Physical Sciences, 6: 5623-5647.

ALMEIDA FILHO GS, SANTORO J \& GOMES LA. 2004. Estudo da dinâmica evolutiva da boçoroca São Dimas no município de São Pedro, SP. In: Simpósio Brasileiro de Desastres Naturais, Florianópolis, Brazil, 73-86.

AZEVEDO AA \& ALBUQUERQUE FILHO JL. 1998. Águas subterrâneas. In: OLIVEIRA AMS (Org.). Geologia de Engenharia. São Paulo - SP, Brazil: ABGE, 111-130.

CHAMBERS JE, KURAS 0, MELDRUM PI, OGILVY RD \& HOLLANDS J. 2006. Electrical resistivity tomography applied to geologic, hydrogeologic, and engineering investigations at a former waste-disposal site. Geophysics, 71: 231-239.

CÔRTES ARP, MOREIRA CA, VELOSO DIK, VIEIRA LB \& BERGONZONI FA. 2016. Geoelectrical prospecting for a copper-sulfide mineralization in the Camaquã sedimentary basin, Southern Brazil. Geofísica Internacional, 55(3): 107-117.

DOURADO JC, MALAGUTTI FILHO W, BRAGA ACO \& NAVA N. 2001. Detecção de cavidades em arenitos utilizando gravimetria, eletrorresistividade e GPR. Brazilian Journal of Geophysics, 19(1): 19-32.

FELL R \& FRY JJ. 2013. State of the Art on the Likelihood of Internal Erosion of Dams and Levees by Means of testing. In: BONELLI S (Ed.). Erosion in Geomechanics Applied to Dams and Levees. Series Editor François Nicot. Wiley, London, $399 \mathrm{pp}$.

GEOTOMO SOFTWARE. 2003. RES2DINV, version 3.53, Rapid 2D resistivity \& IP inversion using the least-square method - Geoelectrical Imaging 2-D \& 3D, Geotomo Software, Penang, Malaysia, 129 pp.
HUNT RE. 2006. Geologic hazards: A Field Guide for Geotechnical Engineers. CRC Press, USA, $334 \mathrm{pp}$.

INFANTI JUNIOR N \& FORNASARI FILHO N. 1998. Processos de dinâmica superficial. In: OLIVEIRA AMS (Org.). Geologia de Engenharia. São Paulo - SP, Brazil: ABGE, 1998, p. 131-152.

KEAREY P, BROOKS M \& HILL I. 2002. Geofísica de Exploração. Tradução de Maria Cristina Moreira Coelho, São Paulo, Brazil: Oficina de Textos, $429 \mathrm{pp}$.

KNÖDEL K, LANGE G \& VOIGT HJ. 2007. Environmental Geology: Handbook of Field Methods and Case Studies. Bundesanstalt für Geowissenschaften und Rohstoffe, Hannover, Federal Institute for Geosciences and Natural Resources. Ed. Springer, 1357 pp.

LAZZARI M, LOPERTE A \& PERRONEA. 2010. Near surface geophysics techniques and geomorphological approach to reconstruct the hazard cave map in historical and urban areas. Advances in Geosciences, 24: 35-44.

MARTINEZ-PAGAN P, GOMEZ-ORTIZ D, MARTIN-CRESPO T, MANTECA JI \& ROSIQUE M. 2013. The electrical resistivity tomography method in the detection of shallow mining cavities. A case study on the Victoria Cave, Cartagena (SE Spain). Engineering Geology, 156: 1-10.

MATHIAS DT. 2011. Proposta de recuperação de áreas peri-urbanas erodidas com base em parâmetros hidrológicos e geomorfológicos: córrego Tucunzinho (São Pedro/SP). Master Dissertation. UNESP/ IGCE - Rio Claro, Brazil, 129 pp.

MOREIRA CA, LAPOLA MM \& CARRARA A. 2016. Comparative analyzes among electrical resistivity tomography arrays in the characterization of flow structure in free aquifer. Geofísica Internacional, 55(2): 119-129.

OKA-FIORI C. 2002. Geomorfologia e dinâmica temporo-espacial da bacia do Rio Itiquira: Pantanal Matogrossense - MT, MS. Ph.D. Thesis. Universidade Estadual Paulista Júlio de Mesquita Filho, Insituto de Geociências e Ciências Exatas, Rio Claro - SP, Brazil. 209 pp.

PÁNEK T, MARGIELEWSKI W, TABORIK P, URBAN J, HRADECKY J \& SZURA C. 2010. Gravitationally induced caves and other discontinuities detected by $2 \mathrm{D}$ electrical resistivity tomography: case studies from the Polish Flysch Carpathians. Geomorphology, 123: 165-180.

SCHNEIDER R, MÜHLMANN H, TOMMASI E, MEDEIROS RA, DAEMON RF \& NOGUEIRA AA. 1974. Revisão Estratigráfica da Bacia do Paraná. In: Anais XXVIII Congr. Bras. Geol., SBG, Porto Alegre, Brazil, 1: 41-65.

SHERIFF RE. 1989. Geophysical Methods. New Jersey, Prentice Hall, 175-201.

SILVA JUNIOR JS, FERREIRA FJF \& STEVANATO R. 2006. Aplicação dos métodos gravimétrico e eletroresistivimétrico-IP em área de risco geotécnico do sistema aquífero cárstico em Almirante Tamandaré-PR. Brazilian Journal of Geophysics, 24(3): 411-428. 
SIMÕES MG \& FITTIPALDI FC. 1992. Fósseis da Região de Rio Claro. Arquivo Municipal, Rio Claro, Brazil, 77 pp.

TELFORD WM, GELDART LP \& SHERIFF RE. 2004. Applied Geophysics. 2nd ed., New York: Cambridge University Press, 774 pp.

Recebido em 14 dezembro, 2015 / Aceito em 30 novembro, 2016

Received on December 14, 2015 / Accepted on November 30, 2016
VIEIRA LB, MOREIRA CA, CÔRTES ARP \& LUVIZOTTO GL. 2016. Geophysical modeling of the manganese deposit for Induced Polarization method in Itapira (Brazil). Geofísica Internacional, 55(2): 107-117. 